\title{
Immunohistochemical Study of KPNA2 Expression in Correlation to PCNA Expression in Colorectal Carcinoma
}

\author{
MARYAM E. ABDO, M.Sc.; HEBA F. HARRAS, M.D.; OMNIA K. RIZK, M.D. and \\ KHAIRIA GAWEESH, M.D.
}

The Department of Pathology, Faculty of Medicine, Tanta University

\begin{abstract}
Background: Colorectal cancer is the third most common cancer worldwide. In Egypt, it ranks the 7 th most common malignant tumor representing $3.47 \%$ of male cancers and $3 \%$ of female cancers. The relative frequency of colorectal cancer is about $9-12 \%$ with high male predominance $3: 1$. The prognostic value of conventional parameters for the evaluation of patient prognosis is limited. So, a need for novel prognostic markers is being largely considered.
\end{abstract}

Aim of Study: The purpose of this study is to detect the immunohistochemical expression of KPNA and PCNA in colorectal carcinoma and correlate their expression with the available clinicopathological parameters to illustrate their prognostic role. Also correlate the relation between KPNA2 immunohistochemical expression and PCNA immunohistochemical expression to evaluate the role of KPNA2 as a proliferative marker.

Material andMethods: Sixty cases of colorectal carcinoma were collected retrospectively. They were stained by $\mathrm{H} \& \mathrm{E}$, KPNA and PCNA for immunohistochemical study. The relations between their expression and the available clinicopathological parameters were evaluated.

Results: KPNA2 expression in colorectal carcinoma showed statistically significant relation with tumor grading, staging, vascular invasion and perineural invasion. PCNA expression showed statistically significant relation with histopathological grading, staging, vascular and perineural invasion. This study observed a strong positive correlation between KPNA2 immunohistochemical score and PCNA immunohistochemical staining in the studied cases.

Conclusions: KPNA2 and PCNA expression can be used as predictive tumor marker which predicts the poor prognosis in colorectal cancer. KPNA2 may have a potential role in tumor cell proliferation.

Key Words: KPNA2 - PCNA - Colorectal carcinoma-Immunohistochemistry - Prognosis.

Correspondence to: Dr. Maryam E. Abdo, The Department of Pathology, Faculty of Medicine, Tanta University

\section{Introduction}

COLORECTAL Cancer (CRC) is a very common malignant tumor of the digestive tract, with about 1.2 million new cases and 600,000 deaths worldwide each year [1]. It is the third most common cancer all over the world [2]

In Egypt, it ranks the 7 th most common malignant tumor representing $3.47 \%$ of male cancers and $3 \%$ of female cancers $[3,4]$. The relative frequency of colorectal cancer is about $9-12 \%$ with high male predominance $3: 1$ [5]. The morbidity and mortality referable to heritable and sporadic carcinomas of the colon are substantial and affect young aged and elderly alike, with CRC being the third most common cause of cancer mortality in the developed world [6]. Indeed, the prognosis of colorectal carcinoma is related to several clinical and pathological parameters including tumor size, stage, and grade. Although these parameters do reflect the biological features of the tumor, they do not fully predict individual clinical outcome. Thus, a need for novel markers for optimum identification of patient's prognosis is being largely regarded. Studies have spotlighted on the possible contribution of new biological factors involved in the carcinogenic process as prognostic markers to help in guessing of clinical outcome of colorectal carcinoma cases [7].

Karyopherin a s are a part of the importin/ karyopherin family and have a role in the procedure of protein carrying from the cytoplasm into the nucleus. Karyopherin a s bind the nuclear localization signals of proteins and moderate the transport of proteins measuring greater than $50 \mathrm{kDa}$ via nuclear pore complexes [8]

Karyopherin a 2 (KPNA2) is an isoform of Karyopherin as and has been demonstrated as a 
marker of bad outcome in many tumors $[9,10]$ However, only small-scale analyses of KPNA2 expression have been performed in CRC [11].

The Proliferating Cell Nuclear Antigen (PCNA) is a non-histamine nuclear protein which arises in two functionally different forms. One of them, whose expression persists stable within the all cycle, is linked to DNA repair. The function of PCNA in this action lies in its interactions with DNA polymerase epsilon, whose fundamental role is DNA repair. The other form acts as an auxiliary protein for DNA polymerase delta, which is the principle replication enzyme [12,13].

As the PCNA expression occurs in proliferating cells, its level can be a marker of cell cycle kinetics and proliferative activity. PCNA level is thought to be related to adverse histopathologic tumor features (the degree of malignancy, vascular invasion, distant metastases) as well as patient survival $[12,13]$. Therefore, PCNA has been described as a remarkable element in the outcome of many tumors including colorectal cancer [14].

\section{Material and Methods}

The present work was carried out on 60 cases of colorectal carcinoma. Cases were retrospectively retrieved from the archives of Tanta Department of Pathology and private laboratories during the period of the research from May 2017 till June 2018 and patients' data were obtained from files of surgery and oncology reports. Approval from Research Ethics Committee (REC), Faculty of Medicine, Tanta University was taken antecedent to conducting study.

Cases were classified microscopically according to the 4th edition of the World Health Organization (WHO) classification system, 2010 [15,16]. Cases were graded into well differentiated (Grade 1), moderately differentiated (Grade 2) and poorly differentiated (Grade 3) carcinomas according to the WHO criteria which was based on the extent of glandular differentiation as the following [17] Grade 1: Showing more than $95 \%$ of gland formation, Grade 2: Gland formation ranged between $50 \%$ and $95 \%$ and Grade 3: gland formation was lower than $50 \%$.

Pathological staging of the studied colorectal carcinomas was determined according to the recommendations of the 8 th edition of AJCC, Cancer Staging Manual, 2017 by using the TNM staging system [18]
Immunohistochemical staining was performed on $10 \%$ formalin fixed, paraffin embedded tissue blocks for evaluation of KPNA2 and PCNA expression. Sections were immunohistochemically labeled, using primary antibodies to KPNA2 (rabbit polyclonal antibody, Kit no. ab84440, Abcam, UK, dilution 1:150) and PCNA (mouse monoclonal antibody, clone number (PC 10), Kit no. AB29, Abcam, UK, dilution 1:10,000). KPNA2 expression was mainly nuclear in the tumor cells. An immunoreactivity scoring system was applied, according to reported procedures [19]. The percentage of positive cells was scored as follows: $0(<5 \%$, negative); 1 (5 25\%, sporadic); 2 (25 50\%, focal); and $3(>50 \%$, diffuse). The staining intensity was scored as follows: 0 , no staining; 1 , weak staining; 2 , moderate staining; and 3, strong staining. The KPNA2 immunostaining score was calculated using the following formula: Immunostaining score= Positive cell score $\mathrm{x}$ staining intensity score. The immunostaining score ranged between 0 and 9 . A score of $>4$ indicated high KPNA2 expression. PCNA expression was mainly nuclear. The reaction to PCNA was evaluated according to the following criteria; () lack of reaction to PCNA or reaction present in $<60 \%$ of cells and $(+)$ reaction present in $>60 \%$ of cells $[\mathbf{1 2 , 1 3}]$.

Chi-square test was used as a test of significance to evaluate the association between categorized variables and $p$-value $<0.05$ was considered statistically significant. Statistical analyses were performed using SPSS software, Version 12.0.

\section{Results}

The clinicopathological characteristics of the studied cases were summarized in (Table 1). We immunohistochemically evaluated 60 cases of colorectal carcinoma specimens for KPNA2 and PCNA expression and study the relation with different clinicopathological parameters (Tables 2,3). The correlation between KPNA2 score and PCNA percent in colorectal carcinoma studied cases was illustrated in (Table 4) and Graph (1).

Among 60 studied colorectal carcinoma cases, thirty-six cases $(60 \%)$ were high KPNA2 expression and twenty-four cases (40\%) were low KPNA2 expression. There was a statistically significant positive relation between KPNA2 expression and histopathological grade $(p=0.005)$, depth of invasion $(p=0.001)$, lymph node status $(p=0.001)$, perineural invasion $(p=0.041)$ and vascular invasion $(p=0.009)$. But didn't show statistically significant relation with histopathological type $(p=0.714)$. 
Out of 60 studied colorectal carcinoma cases, thirty-seven cases $(61.7 \%)$ of cases were PCNA positive and twenty-three $(23 \%)$ of cases were PCNA negative. The PCNA immunohistochemical expression showed statistically significant positive relation with histopathological grade $(p=0.002)$, depth of invasion $(p=0.011)$, lymph node status $(p=0.005)$. But didn't show statistically significant relation with histopathological type ( $p=0.603$ ), vascular invasion $(p=0.061)$ and perineural invasion $(p=0.526)$.

There was a strong positive correlation between KPNA2 immunohistochemical score and PCNA immunohistochemical staining in the studied cases $(r=0.937, p=0.001)$.

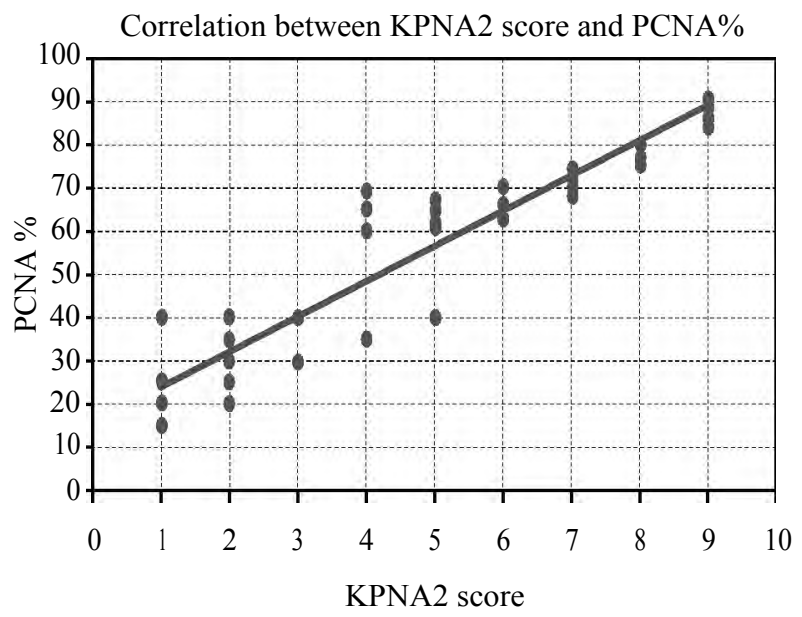

Graph (1): Correlation between KPNA2 score and PCNA\%.

Table (1): Clinicopathological characteristics of the studied cases.

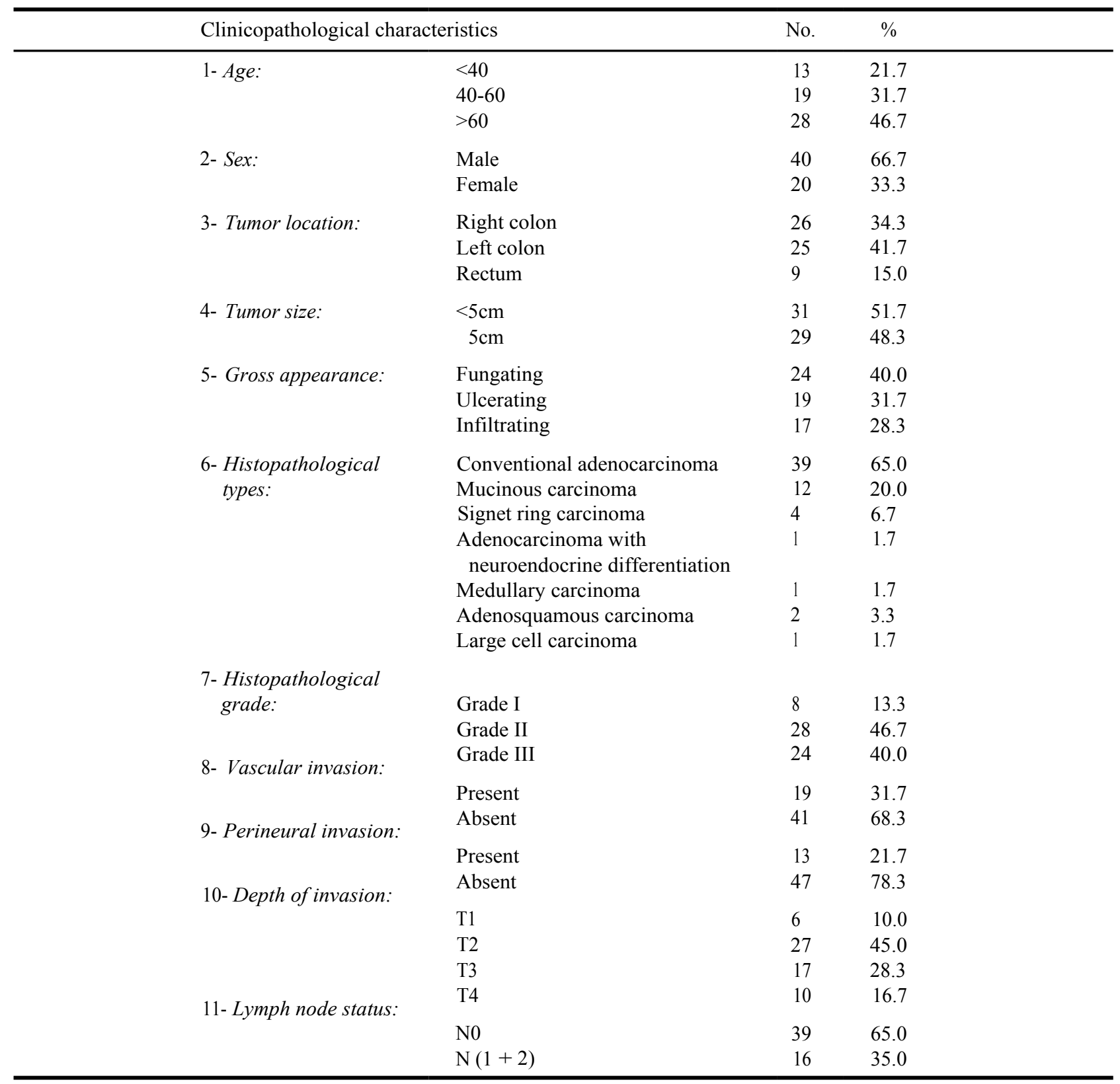


Table (2): Relation between KPNA2 immunohistochemical score and different clinicopathological parameters.

\begin{tabular}{|c|c|c|c|c|c|c|c|c|}
\hline \multirow{3}{*}{ Variables } & & \multirow{3}{*}{$\mathrm{N}$. } & \multicolumn{4}{|c|}{$\begin{array}{c}\text { KPNA2 } \\
\text { immunohistochemical score }\end{array}$} & \multirow{3}{*}{$x^{2}$} & \multirow{3}{*}{$\mathrm{MC}_{p}$} \\
\hline & & & \multicolumn{2}{|c|}{ High } & \multicolumn{2}{|c|}{ Low } & & \\
\hline & & & $\mathrm{N}$. & $\%$ & $\mathrm{~N}$. & $\%$ & & \\
\hline \multirow[t]{6}{*}{ Type: } & Conventional adenocarcinoma & 39 & 22 & 56.4 & 17 & 43.6 & \multirow[t]{7}{*}{3.723} & \multirow[t]{7}{*}{0.714} \\
\hline & Mucinous carcinoma & 12 & 7 & 58.3 & 5 & 41.7 & & \\
\hline & Signet ring carcinoma & 4 & 2 & 50.0 & 2 & 50.0 & & \\
\hline & $\begin{array}{l}\text { Conventional with neuroendocrine } \\
\text { differentiation }\end{array}$ & 1 & 1 & 100.0 & 0 & 0.0 & & \\
\hline & Medullary carcinoma & 1 & 1 & 100.0 & 0 & 0.0 & & \\
\hline & Adenosquamous carcinoma & 2 & 2 & 100.0 & 0 & 0.0 & & \\
\hline \multirow{3}{*}{ Grade: } & Large cell carcinoma & 1 & 1 & 100.0 & 0 & 0.0 & & \\
\hline & Grade I & 8 & 2 & 25.0 & 6 & 75.0 & \multirow[t]{3}{*}{10.694} & \multirow[t]{3}{*}{0.005} \\
\hline & Grade II & 28 & 14 & 50.0 & 14 & 50.0 & & \\
\hline \multirow{4}{*}{$\begin{array}{l}\text { The depth of } \\
\text { the invasion: }\end{array}$} & Grade III & 24 & 20 & 83.3 & 4 & 16.7 & & \\
\hline & $\mathrm{T} 1$ & 6 & 1 & 16.7 & 5 & 83.3 & \multirow[t]{4}{*}{23.969} & \multirow[t]{4}{*}{0.001} \\
\hline & $\mathrm{T} 2$ & 27 & 13 & 48.1 & 14 & 51.9 & & \\
\hline & $\mathrm{T} 3$ & 17 & 13 & 76.5 & 4 & 23.5 & & \\
\hline \multirow{2}{*}{$\begin{array}{l}\text { The lymph } \\
\text { node status: }\end{array}$} & $\mathrm{T} 4$ & 10 & 9 & 90.0 & 1 & 10.0 & & \\
\hline & No & 39 & 16 & 41.0 & 23 & 59.0 & \multirow[t]{2}{*}{16.716} & \multirow[t]{2}{*}{0.001} \\
\hline \multirow{2}{*}{$\begin{array}{l}\text { The vascular } \\
\text { invasion: }\end{array}$} & $\mathrm{N}(1+2)$ & 21 & 20 & 95.2 & 1 & 4.8 & & \\
\hline & Present & 19 & 16 & 84.2 & 3 & 15.8 & \multirow[t]{2}{*}{6.791} & \multirow[t]{2}{*}{0.009} \\
\hline \multirow{3}{*}{$\begin{array}{l}\text { The perineural } \\
\text { invasion: }\end{array}$} & Abscent & 41 & 20 & 48.8 & 21 & 51.2 & & \\
\hline & Present & 13 & 11 & 84.6 & 2 & 15.4 & \multirow[t]{2}{*}{4.190} & \multirow[t]{2}{*}{0.041} \\
\hline & Absent & 47 & 25 & 53.2 & 22 & 46.8 & & \\
\hline
\end{tabular}

Table (3): Relation between PCNA immunohistochemical score and different clinicopathological parameters.

\begin{tabular}{|c|c|c|c|c|c|c|c|c|}
\hline \multirow{3}{*}{ Variables } & & \multirow{3}{*}{$\mathrm{N}}$. & \multicolumn{4}{|c|}{$\begin{array}{c}\text { PCNA } \\
\text { immunohistochemical score }\end{array}$} & \multirow{3}{*}{$x^{2}$} & \multirow{3}{*}{$\mathrm{MC}_{p}$} \\
\hline & & & \multicolumn{2}{|c|}{ Positive } & \multicolumn{2}{|c|}{ Negative } & & \\
\hline & & & $\mathrm{N}$. & $\%$ & $\mathrm{~N}$. & $\%$ & & \\
\hline \multirow[t]{6}{*}{ Type: } & Conventional adenocarcinoma & 39 & 21 & 53.8 & 18 & 46.2 & \multirow[t]{7}{*}{4.545} & \multirow[t]{7}{*}{0.603} \\
\hline & Mucinous carcinoma & 12 & 8 & 66.7 & 4 & 33.3 & & \\
\hline & Signet ring carcinoma & 4 & 3 & 75.0 & 1 & 25.0 & & \\
\hline & $\begin{array}{l}\text { Conventional with neuroendocrine } \\
\text { differentiation }\end{array}$ & 1 & 1 & 100.0 & 0 & 0.0 & & \\
\hline & Medullary carcinoma & 1 & 1 & 100.0 & 0 & 0.0 & & \\
\hline & Adenosquamous carcinoma & 2 & 2 & 100.0 & 0 & 0.0 & & \\
\hline \multirow{3}{*}{ Grade: } & Large cell carcinoma & 1 & 1 & 100.0 & 0 & 0.0 & & \\
\hline & Grade I & 8 & 2 & 25.0 & 6 & 75.0 & \multirow[t]{3}{*}{12.938} & \multirow[t]{3}{*}{0.002} \\
\hline & Grade II & 28 & 14 & 50.0 & 14 & 50.0 & & \\
\hline \multirow{4}{*}{$\begin{array}{l}\text { The depth of } \\
\text { the invasion: }\end{array}$} & Grade III & 24 & 21 & 87.5 & 3 & 12.5 & & \\
\hline & $\mathrm{T} 1$ & 6 & 1 & 16.7 & 5 & 83.3 & \multirow[t]{4}{*}{11.212} & \multirow[t]{4}{*}{0.011} \\
\hline & $\mathrm{T} 2$ & 27 & 14 & 51.9 & 13 & 48.1 & & \\
\hline & $\mathrm{T} 3$ & 17 & 13 & 76.5 & 4 & 23.5 & & \\
\hline \multirow{2}{*}{$\begin{array}{l}\text { The lymph } \\
\text { node status: }\end{array}$} & $\mathrm{T} 4$ & 10 & 9 & 90.0 & 1 & 10.0 & & \\
\hline & No & 39 & 19 & 48.7 & 20 & 51.3 & \multirow[t]{2}{*}{7.904} & \multirow[t]{2}{*}{0.005} \\
\hline \multirow{2}{*}{$\begin{array}{l}\text { The vascular } \\
\text { invasion: }\end{array}$} & $\mathrm{N}(1+2)$ & 21 & 18 & 85.7 & 3 & 14.3 & & \\
\hline & Present & 19 & 15 & 78.9 & 4 & 21.1 & \multirow[t]{2}{*}{3.513} & \multirow[t]{2}{*}{0.061} \\
\hline \multirow{3}{*}{$\begin{array}{l}\text { The perineural } \\
\text { invasion: }\end{array}$} & Abscent & 41 & 22 & 53.7 & 19 & 46.3 & & \\
\hline & Present & 13 & 9 & 69.2 & 4 & 30.8 & \multirow[t]{2}{*}{0.402} & \multirow[t]{2}{*}{0.526} \\
\hline & Absent & 47 & 28 & 59.6 & 19 & 40.4 & & \\
\hline
\end{tabular}




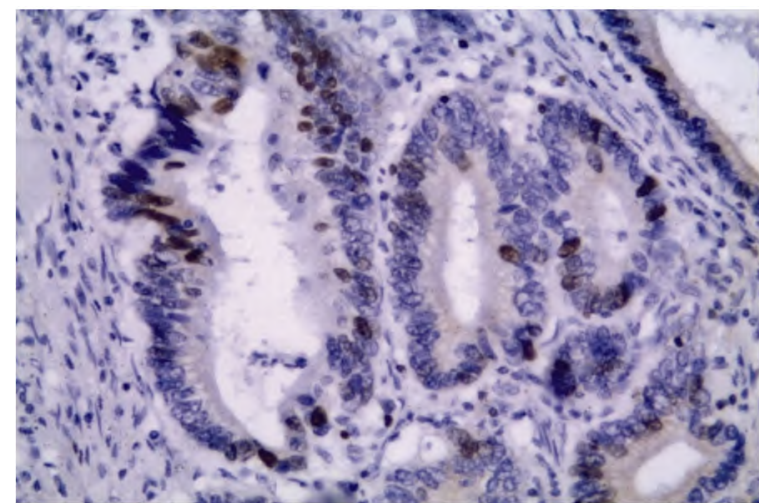

(A)

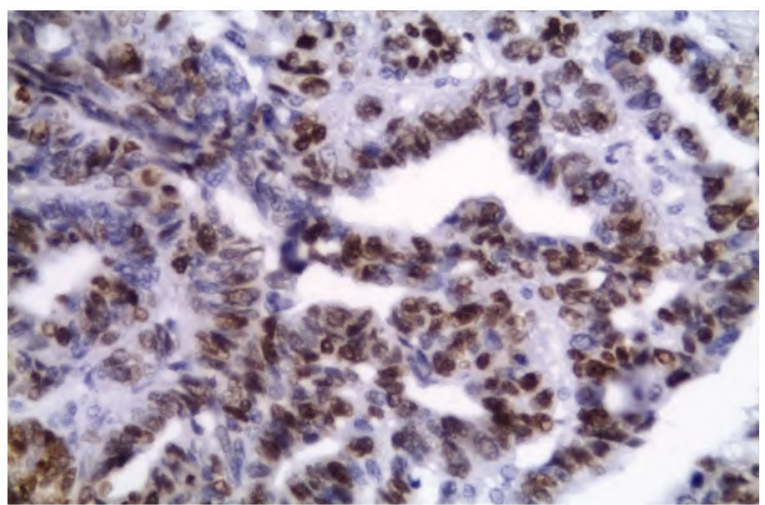

(B)

Fig. (1): (A) Conventional adenocarcinoma (grade II) showing low KPNA2 expression (X400). (B) Conventional adenocarcinoma (grade III) showing high KPNA2 expression (X400).

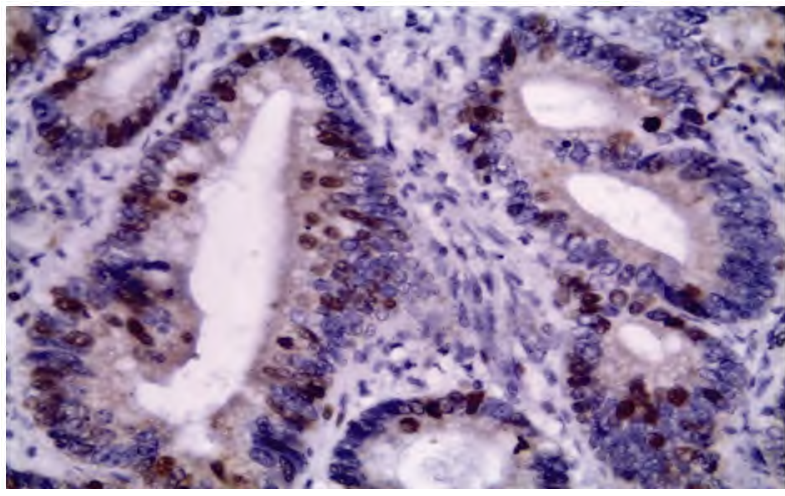

(A)

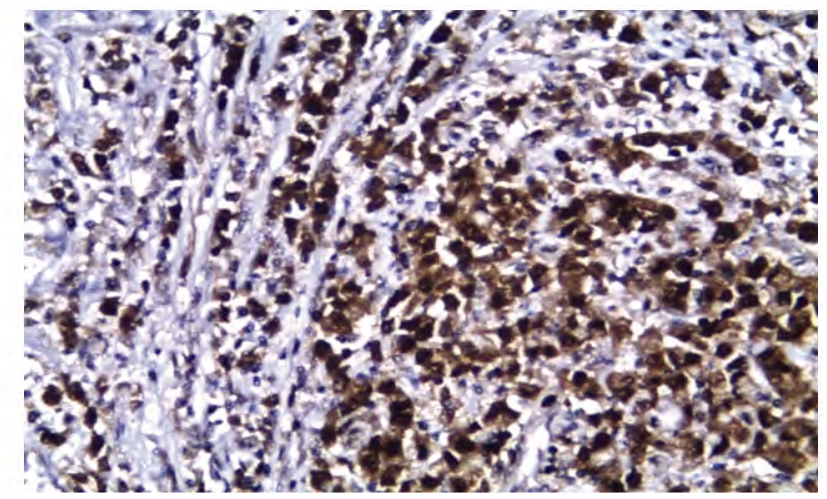

(B)

Fig. (2): (A) Conventional adenocarcinoma (grade II) showing negative nuclear PCNA staining (X400). (B) Conventional adenocarcinoma (grade III) showing POSITIVE nuclear PCNA staining (X400).

Table (4): Correlation between KPNA2 score and PCNA\%.

\begin{tabular}{cc}
\hline Correlation & KPNA2 score \\
\hline$P C N A \%:$ & \\
$r$ & 0.937 \\
$p$ & $0.001^{*}$ \\
\hline
\end{tabular}

\section{Discussion}

KPNA2 is an essential carrier that help in active transport of macromolecular cargo proteins between the cytoplasm and nucleus [20]. Many studies had noticed elevated levels of KPNA2 in a variety of malignancies after recognition of the prognostic significance of KPNA2 expression in breast carcinoma by Dahl et al., 2006 [21] . Aberrant KPNA2 levels has been described in a variety of other cancer forms. These include cervical cancer [22] esophageal cancer [23], lung cancer [24], ovarian cancer [25], prostate cancer [26], brain cancer [27], liver cancer [28] and bladder cancer [29]. Most of these researches have explored the association between KPNA2 levels and case prognosis. Irrespective of cancer type, high levels of KPNA2 has been revealed to be associated with bad outcome [30]

As regards to KPNA2 expression in the studied cases, there was statistically significant positive relation between KPNA2 immunohistochemical expression and the histopathological grade of the tumor. Similar results were detected by Zhang et al., (2015) [31] . This significant relation could be explained by the following; the increased KPNA2 expression detected in cancer tissues is mainly localized to the nucleus of cell. This may be due to cellular stress, including oxidative stress and heat shock, which may lead to the collection of KPNA2 in the nucleus of cells. It has been noticed that cells in high grade tumors typically exhibit a high level of oxidative stress $[33,34]$. There was a statistically significant positive relation between KPNA2 immunohistochemical expression and depth of tumor invasion (T). Similar results were detected by Rachidi et al., (2013) in cancer colon [35]. There was statistically significant positive relation between KPNA2 immunohistochemical expression and lymph node status $(\mathrm{N})$, vascular 
invasion and perineural invasion. Similar results were detected by Zhang et al. (2015) \& Jeong et al. (2017) in cancer colon [31,32]. There was no significant relation between KPNA2 immunohistochemical expression and histopathological type. The significant relation between the studied pathological parameters (depth of invasion, lymph node involvement, perivascular invasion and perineural invasion) and KPNA2 immunohistochemical expression can be explained by the following; Two cell cycle checkpoint mediators, Nijmegen Breakage Syndrome 1 (NBS1) and Checkpoint Kinase 2 (CHK2), have been demonstrated to be regulated by KPNA2 [36,37]. Chk2 is translocated by KPNA2. Zannini et al., (2003) found that overexpression of KPNA2 correlates with an increase CHK2 nuclear import [38] that indicates aggressiveness and impacts negatively patient survival and outcome in many solid tumors including cancer colon [39]. Also, Mutations in CHK2 allow the cells to survive the repair mechanisms, which culminates in proliferation and survival of abnormal cells and results in increased genetic instability and tumor progression [40] According to Sandrock et al., (2010) \& Li et al., (2011), RAC-1 is also translocated by KPNA2 $[41,42]$ which play a role in cell cycle progression, cellular adhesion and migration [43]. RAC-1 role in promoting cancer colon progression was studied by Espina et al., (2008) [44]. Furthermore, KPNA2 is responsible for the import of NBS1, another DNA repair protein which also partake in carcinogenesis [45]

Also, there was a systematic review and metaanalysis [46] that demonstrated the prognostic role of KPNA2 expression in some tumors collecting 24 studies of KPNA2 expression in different cancers and concluded that there is a significant association between KPNA2 immunohistochemical expression of solid tumors including cancer colon and primary outcome (overall survival) (Hazard Ratio; HR=1.767), secondary outcome (time to recurrence, recurrence free survival, progression free survival). The finding of this meta-analysis with the studied pathological parameters indicate that KPNA2 can be a helpful marker to detect colorectal carcinoma outcome.

Studies of PCNA expression in relation to the cell cycle revealed that PCNA levels are high during late G1 before onset of DNA synthesis, thereafter, reaching the highest point during Sphase with a decrease in G2 and M phases of the cell cycle and thus in this way the high elevation of PCNA levels correlated with cell proliferation and synthesis of DNA [47].
Expression of PCNA have been observed in a variety of malignancies; breast cancer [48], Lymphoma [49], Hepatocellular carcinoma [50], Cervical carcinoma [51]. As regards to PCNA expression in these studied cases, there was significant positive relation between PCNA expression and histopathological grade, depth of invasion \& lymph node status $(\mathrm{N})$. There was no significant relation between PCNA immunohistochemical expression and histopathological types, vascular invasion and perineural invasion. The same result was detected by Guzinska-Ustymowicz et al., (2008) [13,52]

There was strong positive correlation between KPNA2 and PCNA immunohistochemical expression. This result can explain the role of KPNA2 in cellular proliferation. The proliferative role of KPNA2 also had been studied by Zhang et al., (2015) [31] when they correlate the relation between KPNA2 immuno-histochemical expression and the presence of $\mathrm{Ki}-67$ which is a proliferative marker too and found a positive correlation between them. This also was supported by the results in other solid cancers like Gluz et al., (2008) in breast cancer [9]; Sakai et al., (2010) in oesphageal cancer [10] and Gousias et al., (2012) in astrocytoma [53] All these studies including the current one suggests that KPNA2 may have a potential role in colon cancer cell proliferation as PCNA and useful predictive marker for poor prognosis.

\section{Conflict of interest:}

None declared.

\section{References}

1- RASKOV H., POMMERGAARD H.C., BURCHARTH J., et al.: Colorectal carcinogenesis--update and perspectives. World J. Gastroenterol., 20: 18151-64, 2014.

2- SIEGEL R.L., MILLER K.D. and JEMAL A.: Cancer statistics, 2016. CA: A Cancer Journal for Clinicians, 66 (1): 7-30, 2016.

3- METWALLY I.H., SHETIWY M., ELALFY A.F., et al.: Epidemiology and survival of colon cancer among Egyptians: A retrospective study. J. Coloproctol., 2017.

4- MAHFOUZ E.M., SADEK R.R., ABDEL-LATIEF W.M., et al.: The role of dietary and lifestyle factors in the development of colorectal cancer: Case control study in Minia, Egypt. Cent. Eur. J. Public Health, 22 (4): 215 $22,2014$.

5- KAZEM A., EL-SAYED K., EL-KERM Y., et al.: Prognostic significance of COX2 and B-catenin in colorectal carcinoma. Alex. J. Med., 50: 211-20, 2014.

6- LÓPEZ P.J.T., ALBERO J.S. and RODRÍGUEZ-MONTES J.A.: Primary and secondary prevention of colorectal 
cancer. Clin. Med. Insights: Gastroenterol., 7: 33-46, 2014.

7- JIANG L., WU J.T. and PENG X.: Primary choriocarcinoma of the colon: A case report and review of the literature. World Journal of Surgical Oncology, 11: 1-5, 2013.

8- LANGE A., MILLS R.E., LANGE C.J., STEWART M., DEVINE S.E. and CORBETT A.H.: Classical nuclear localization signals: Definition, function, and interaction with importin $\alpha$. Journal of Biological Chemistry, 282 (8): 5101-5, 2007.

9- GLUZ O., WILD P., MEILER R., DIALLODANEBROCK R., TING E., MOHRMANN S. and HERR A.: Nuclear karyopherin $\alpha 2$ expression predicts poor survival in patients with advanced breast cancer irrespective of treatment intensity. International Journal of Cancer, 123 (6): 1433-8, 2008.

10- SAKAI M., SOHDA M., MIYAZAKI T., SUZUKI S., SANO A., TANAKA N. and KUWANO H.: Significance of karyopherin- $\alpha 2$ (KPNA2) expression in esophageal squamous cell carcinoma. Anticancer Research, 30 (3): 851-6, 2010.

11- RACHIDI S.M., QIN T., SUN S., ZHENG W.J. and LI Z.: Molecular profiling of multiple human cancers defines an inflammatory cancer-associated molecular pattern and uncovers KPNA2 as a uniform poor prognostic cancer marker. PLoS One, 8: 1-14, 2013.

12- GUZINSKA-USTYMOWICZ K., PRYCZYNICZ A., KEMONA A. and CZY ŻEWSKA J.: Correlation between proliferation markers: PCNA, Ki-67, MCM-2 and antiapoptotic protein $\mathrm{Bcl}-2$ in colorectal cancer. Anticancer Research, 29 (8): 3049-52, 2009.

13- GUZINSKA-USTYMOWICZ K., STEPIEN E. and KEMONA A.: MCM-2, Ki-67 and PCNA protein expressions in pT3G2 colorectal cancer indicated lymph node involvement. Anticancer Research, 28: 451-7, 2008.

14- JINGLI Z., HONGYING Z., HONG B., JIE Z., PING Y., BING W. and ZHANG Z.: Comparison between expression of Ki-67 and PCNA in breast carcinoma. Chinese Journal of Clinical and Experimental Pathology, 1: 23, 2003.

15- BAE J.M., LEE T.H., CHO N.Y., et al.: Loss of CDX2 expression is associated with poor prognosis in colorectal cancer patients. World J. Gastroenterol., 21: 1457-67, 2015.

16- BONHOMME C., DULUC I., MARTIN E., et al.: The $\mathrm{Cdx} 2$ homeobox gene has a tumour suppressor function in the distal colon in addition to a homeotic role during gut development. Gut., 52 (10): 1465-71, 2003.

17-WERLING R.W., YAZIJI H., BACCHI C.E., et al.: CDX2, a highly sensitive and specific marker of adenocarcinomas of intestinal origin: An immunohistochemical survey of 476 primary and metastatic carcinomas. The American Journal of Surgical Pathology, 27 (3): 303-10, 2003.

18- SLATTERY M.L., HERRICK J., WOLFF R.K., et al.: CDX2 VDR polymorphism and colorectal cancer. Cancer Epidemiology and Prevention Biomarkers, 16 (12): 27525, 2007.
19- WINNEPENNINCKX V., LAZAR V., MICHIELS S., DESSEN P., STAS M., ALONSO S.R. and BALACESCU O.: Gene expression profiling of primary cutaneous melanoma and clinical outcome. Journal of the National Cancer Institute, 98 (7): 472-82, 2006.

20- LANGE A., MILLS R.E., LANGE C.J., STEWART M., DEVINE S.E. and CORBETT A.H.: Classical nuclear localization signals: Definition, function, and interaction with importin $\alpha$. Journal of Biological Chemistry, 282 (8): 5101-5, 2007.

21- DAHL E., KRISTIANSEN G., GOTTLOB K., KLAMAN I., EBNER E., HINZMANN B., HERMANN K., PILARSKY C., DÜRST M. and KLINKHAMMER-SCHALKE M.: Molecular profiling of laser-microdissected matched tumor and normal breast tissue identifies karyopherin $\alpha 2$ as a potential novel prognostic marker in breast cancer. Clinical Cancer Research, 12: 3950-60, 2006.

22- VAN DER WATT P.J., MASKE C.P., HENDRICKS D.T., PARKER M.I., DENNY L., GO VENDER D. and LEANER V.D.: The Karyopherin proteins, Crm1 and Karyopherin $\beta 1$, are overexpressed in cervical cancer and are critical for cancer cell survival and proliferation. International Journal of Cancer, 124 (8): 1829-40, 2009.

23- SAKAI M., SOHDA M., MIYAZAKI T., SUZUKI S., SANO A., TANAKA N. and KUWANO H.: Significance of karyopherin- $\alpha 2$ (KPNA2) expression in esophageal squamous cell carcinoma. Anticancer Research, 30 (3): 851-6, 2006.

24- WANG C.I., CHIEN K.Y., WANG C.L., LIU H.P., CHENG C.C., CHANG Y.S. and YU C.J.: Quantitative proteomics reveals regulation of karyopherin subunit alpha-2 (KPNA2) and its potential novel cargo proteins in nonsmall cell lung cancer. Molecular \& Cellular Proteomics, 11 (11): 1105-22, 2012.

25- ZHENG M., TANG L., HUANG L., DING H., LIAO W.T., ZENG M.S. and WANG H.Y.: Overexpression of karyopherin-2 in epithelial ovarian cancer and correlation with poor prognosis. Obstetrics \& Gynecology, 116 (4): 884-91, 2010.

26- MORTEZAVI A., HERMANNS T., SEIFERT H.H., BAUMGARTNER M., PROVENZANO M., SULSER T. and HOFSTÄDTER F.: KPNA2 expression is an independent adverse predictor of biochemical recurrence after radical prostatectomy. Clinical Cancer Research, 17 (5): 1111-21, 2011.

27- GOUSIAS K., BECKER A.J., SIMON M. and NIEHUSMANN P.: Nuclear karyopherin a2: A novel biomarker for infiltrative astrocytomas. Journal of Neuro-Oncology, 109 (3): 545-53, 2012.

28- YOSHITAKE K., TANAKA S., MOGUSHI K., AIHARA A., MURAKATA A., MATSUMURA S. and NOGUCHI N.: Importin- $\alpha 1$ as a novel prognostic target for hepatocellular carcinoma. Annals of Surgical Oncology, 18 (7): 2093-103, 2011.

29- JENSEN J.B., MUNKSGAARD P.P., SØRENSEN C.M., FRISTRUP N., BIRKENKAMP-DEMTRODER K., ULHØI B.P. and DYRSKJØT L.: High Expression of Karyopherin- $\alpha 2$ Defines Poor Prognosis in Non-MuscleInvasive Bladder Cancer and in Patients with Invasive Bladder Cancer Undergoing Radical Cystectomy. European Urology, 59 (5): 841-8, 2011. 
30- CHRISTIANSEN A. and DYRSKJøT L.: The functional role of the novel biomarker karyopherin $\alpha 2$ (KPNA2) in cancer. Cancer Letters, 331 (1): 18-23, 2013.

31- ZHANG Y., ZHANG M., YU F., LU S., SUN H., TANG H. and PENG Z.: Karyopherin alpha 2 is a novel prognostic marker and a potential therapeutic target for colon cancer. Journal of Experimental \& Clinical Cancer Research, 34 (1): 145-51, 2015.

32- JEONG D., KIM H., BAN S., OH S., JI S., KIM D., AHN T.S., KIM H.J., BAE S.B. and KWON H.Y.: Karyopherin $\alpha-2$ is a reliable marker for identification of patients with high-risk stage II colorectal cancer. Journal of Cancer Research and Clinical Oncology, 143: 2493-503, 2017.

33- MIYAMOTO Y., SAIWAKI T., YAMASHITA J., YASUDA Y., KOTERA I., SHIBATA S. and YONEDA Y.: Cellular stresses induce the nuclear accumulation of importin $\alpha$ and cause a conventional nuclear import block. The Journal of Cell Biology, 165 (5): 617-23, 2004.

34- TRACHOOTHAM D., ALEXANDRE J. and HUANG P.: Targeting cancer cells by ROS-mediated mechanisms: A radical therapeutic approach? Nature Reviews Drug Discovery, 8 (7): 579-91, 2009.

35- RACHIDI S.M., QIN T., SUN S., ZHENG W.J. and LI Z.: Molecular profiling of multiple human cancers defines an inflammatory cancer-associated molecular pattern and uncovers KPNA2 as a uniform poor prognostic cancer marker. PLoS One, 8: 1-14, 2013.

36- ZANNINI L., LECIS D., LISANTI S., BENETTI R., BUSCEMI G., SCHNEIDER C. and DELIA D.: Karyopherin- $\alpha 2$ protein interacts with Chk 2 and contributes to its nuclear import. Journal of Biological Chemistry, 278 (43): 42346-51, 2013.

37- TSENG S.F., CHANG C.Y., WU K.J. and TENG S.C. : Importin KPNA2 is required for proper nuclear localization and multiple functions of NB S1 . Journal of Biological Chemistry, 280: 3 9594-600, 2005.

3 8- ZANNINI L., LECIS D., LISANTI S., BENETTI R., BUSCEMI G., SCHNEIDER C. and DELIA D.: Karyopherin- $\alpha 2$ protein interacts with Chk 2 and contributes to its nuclear import. Journal of Biological Chemistry, 278 (43): 42346-51, 2003.

39- RIBEIRO K.B., Da SILVA ZANETTI J., RIBEIRO SILVA A., PANSANI F., GARCIA S.B., et al.: CHK2 Immunohistochemical Expression in Colon Cancer and its Relation with Clinicopathological Features and Outcome in Metastatic Colon Cancer Patients. J. Cytol. Histol., 5: 288-90, 2014.

40- WILLIAMS L.H., CHOONG D., JOHNSON S.A. and CAMPBELL I.G.: Genetic and epigenetic analysis of CHEK2 in sporadic breast, colon and ovarian cancers. Clinical Cancer Research, 12 (23): 6967-72, 2006.

41- SANDROCK K., BIELEK H., SCHRADI K., SCHMIDT G. and KLUGBAUER N.: The nuclear import of the small GTPase Rac1 is mediated by the direct interaction with karyopherin $\alpha 2$. Traffic, 11: 198-209, 2010.

42- LI W., YE F., WANG D., SUN X., TONG W., LIAN G., JIANG J., SUO J. and ZHANG D.Y.: Protein predictive signatures for lymph node metastasis of gastric cancer. International Journal of Cancer, 132: 1851-9, 2013.

43- PANKOV R., ENDO Y., EVEN-RAM S., ARAKI M., CLARK K., CUKIERMAN E., MATSUMOTO K. and YAMADA K.M.: A rac switch regulates random versus directionally persistent cell migration. Journal of Cell Biology, 170: 793-802, 2005.

44- ESPINA C., CÉSPEDES M.V., GARCÍA-CABEZAS M.A., DEL PULGAR M.T.G., BOLUDA A., OROZ L.G. and LACAL J.C.: A critical role for Rac1 in tumor progression of human colorectal adenocarcinoma cells. The American Journal of Pathology, 172 (1): 156-66, 2008.

45- TENG S.C., WU K. , TSENG S., WONG C.W. and KAO L.: Importin KPNA2, NBS1, DNA repair and tumorigenesis. Journal of Molecular Histology, 37 (5-7): 293-9, 2006.

46- ZHOU L.N., TAN Y., LI P., ZENG P., CHEN M.B., TIAN Y. \& ZHU Y.Q. : Prognostic value of increased KPNA2 expression in some solid tumors: A systematic review and meta-analysis. Oncotarget, 8: 303-14, 2017.

47- HALL P.A., LEVISON D.A., WOODS A.L., YU C., KELLOCK D.B., WATKINS J.A. and DOVER R.: Proliferating cell nuclear antigen (PCNA) immunolocalization in paraffin sections: An index of cell proliferation with evidence of deregulated expression in some, neoplasms. The Journal of Pathology, 162 (4): 285-94, 1990.

48- JINGLI Z., HONGYING Z., HONG B., JIE Z., PING Y. , BING W. and ZHANG Z.: Comparison between expression of Ki-67 and PCNA in breast carcinoma [J]. Chinese Journal of Clinical and Experimental Pathology, $1: 23$, 2003.

49- RABENHORST S.H., BURINI R.C. and SCHMITT F.C.: Proliferating cell nuclear antigen (PCNA) in non-Hodgkin's lymphomas: Correlation with working formulation and Kiel classification in formalin-fixed paraffin-embedded material. Pathology, 28 (1): 12-6, 1996.

50- CLAUDIO P.P., RUSSO G., KUMAR C.A.C.Y., MINIMO C., FARINA A., TUTTON S. and MARIA V.: pRb2/p130, vascular endothelial growth factor, p27 (KIP 1): And proliferating cell nuclear antigen expression in hepatocellular carcinoma: Their clinical significance. Clinical Cancer Research, 10 (10): 3509-17, 2004.

5 1- WANG J.L., ZHENG B.Y., LI X.D., ÅNGSTRÖM T., LINDSTRÖM M.S. and WALLIN K.L.: Predictive significance of the alterations of p16INK4A, p14ARF, p53, and proliferating cell nuclear antigen expression in the progression of cervical cancer. Clinical Cancer Research, 10 (7): 2407-14, 2004.

52- QASIM B.J., ALI H.H. and HUSSEIN A.G.: Immunohistochemical Expression of PCNA and CD34 in Colorectal Adenomas and Carcinomas Using Specified Automated Cellular Image Analysis System: A Clinicopathologic Study. Saudi Journal of Gastroenterology: Official Journal of the Saudi Gastroenterology Association, 18: 268-76, 2012.

53- GOUSIAS K., BECKER A.J., SIMON M. and NIEHUSMANN P.: Nuclear karyopherin a2: A novel biomarker for infiltrative astrocytomas. Journal of Neuro-Oncology, 109 (3): 545-53, 2012. 


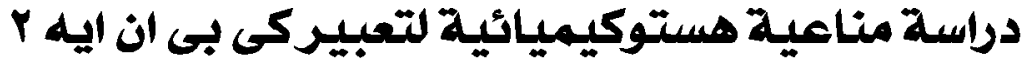

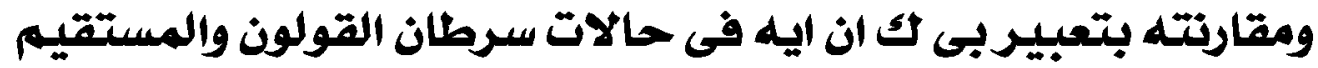

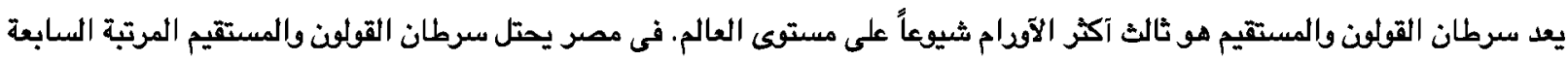

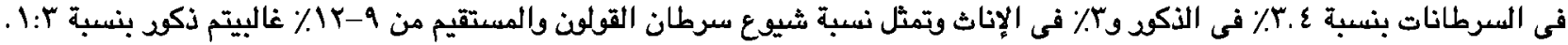

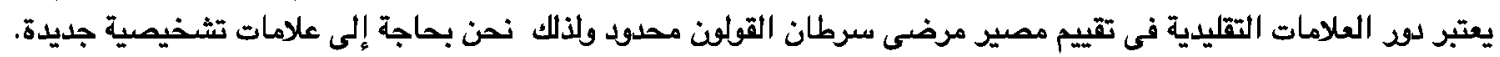

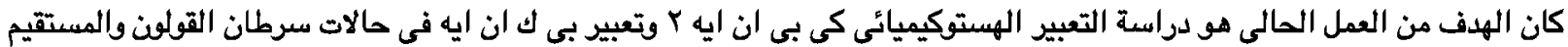

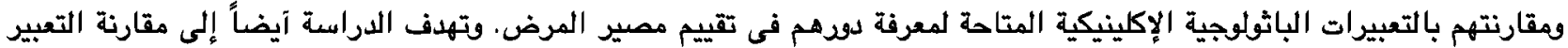

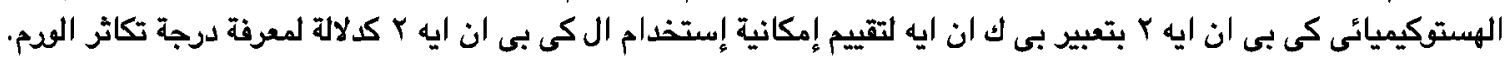

تم عمل هذه الدراسة على •7 حالة من سرطان القولون والمستقيم والتى تم تجميعها بآثر رجعى. وتم صبغهم بصبغة الهيماتوكسيلين

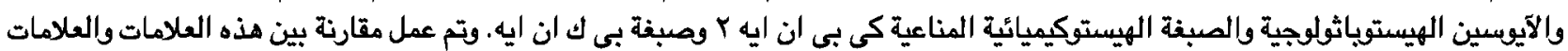
الباثولوجية الإكلينيكية المتاحة.

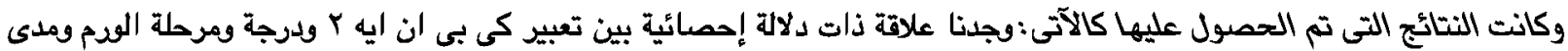

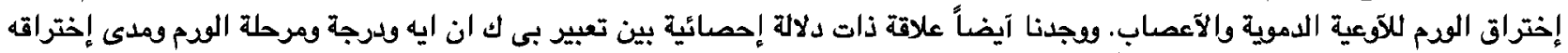

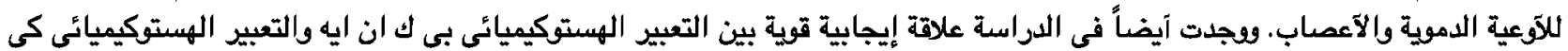
بي ان ايه r.

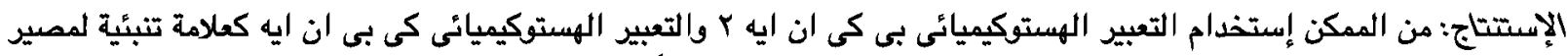

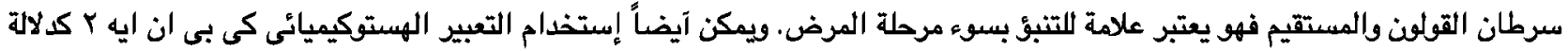

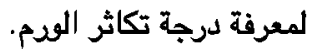

